\title{
The Discourse of Multiculturalism: An Obstacle to Cultural Change?
}

\author{
Anne Sofie Roald
}

\begin{abstract}
This article discusses how the discourse of multiculturalism affects religious and cultural changes in the Muslim communities in Sweden and Norway, particularly with reference to gender and gender relations. Although the two societies have few multicultural policies, the discourse on multiculturalism has still led to claims for legal pluralism. However, it seems that there is an obvious change of attitudes to such claims between the first-generation Muslim immigrants and their descendants, second-generation Norwegian and Swedish Muslims.
\end{abstract}

This article looks at the discourse of multiculturalism and investigates whether this discourse might be an obstacle to certain cultural and religious changes that Swedish and Norwegian public policy seeks to foster, particularly when it comes to gender and gender relations in Muslim communities. The empirical data is gathered in Sweden and Norway through research in Muslim communities in the two countries from the late 1980s onwards. ${ }^{1}$

In the two countries, as elsewhere, from the turn of the twenty-first century public debates on minority women's rights reflect the arguments promoted by Susan Moller Okin in her essay, 'Is Multiculturalism Bad for Women?' (1997). This discussion seems

\footnotetext{
${ }^{1}$ See Roald 2005; 2009. These two books build on extensive field work in Norway and Sweden from the late 1980 s to 2009 . The interviews have mainly focused on gender relations in Islam as well as family law issues in Muslim communities in the two countries. The interviewees have been mainly Muslim community leaders, men and women from the first-generation Muslim immigrant community and from the next or second-generation of Muslims, i.e., the first generation of Norwegian and Swedish Muslims.
} 
to have marked a turning point for the common acceptance of multiculturalism as a sought-after social system. This change in attitude can be seen in Sweden in the change in official terminology from 'multiculturalism' (mångkulturalism) and 'multicultural society' (det mångkulturella samhälle) at the beginning of the 1990s to 'diversity' (mångfald) from the late 1990s onwards (Roald 2009:41-2). It is also interesting to note that with the change of concept the Swedish official migrant policy changed focus from the previous emphasis on the guarantee of freedom of choice for members of linguistic minorities domiciled in Sweden between retaining and developing their original cultural identity and assuming a Swedish cultural identity (SOU 1974), to see integration in terms of participation in the labour market (Roald 2009:41).

Researchers and thus most probably policy makers in both Norway and Sweden seem to have been influenced by the writings of Canadian liberal political scientists and philosophers, such as Will Kymlicka (1995a; 1995b) and Charles Taylor (1994) (see for instance Brochman 2003; Roth 1996). Kymlicka and Taylor discussed issues of cultural pluralism in fairly positive terms during the 1990s, promoting majority recognition for minorities and the strengthening of cultural elements in minority communities. Their publications from the 1990s, although presented in general terms, tended however to draw their conclusions on the empirical reality of aboriginal or historically established communities, such as the indigenous Innuits (Kymlicka 1995 a; 1995b) and the French minority in Canada (Taylor 1994).

The Swedish debate in the 1990s reflected the two Canadian philosophers' liberal approach without discussing the difference between the indigenous Scandinavian Sami population and the 'new' immigrant population. The Swedish philosopher Hans-Ingvar Roth, who has been an active participant in the official space, wrote for instance in 1996 about borders for 'desired' cultural pluralism and how to deal with intercultural conflicts (Roth 1996:11). His approach in the 1990s was clearly that of a group-rights perspective. One example is his discussion about how teachers should treat pupils with a non-Swedish ethnic background. He promoted a diplomatic approach: 'The teacher can through an individualized education form avoid objectionable elements' (Roth 
1996:92), a proposal to which teachers often objected. ${ }^{2}$ However, Roth was more concerned about women's rights within minority cultures than were Kymlicka and Taylor. Indeed he preceded Okin's discussion of women's rights, probably due to the Swedish emphasis on equal gender opportunities.

Okin's reaction to these liberals' positive evaluations of multiculturalism was built on feminist thought. Okin, although also based in a similar liberal tradition to Kymlicka and Taylor, went further than classical liberalism, taking the step of including the private sphere into the multicultural discourse. Okin questions, for instance, Kymlicka's confidence in liberal values, particularly concerning family issues, having penetrated minority communities even in Western countries. It seems however that the disagreement is built on different presuppositions for their argumentation; Okin speaks in terms of the new immigrant communities (Okin 1997), whereas Kymlicka mainly speaks about ethnic and national minorities (Kymlicka 1995a). The apparent disagreement between the two seems to have been symptomatic of the international debate on pluralism in Western society from the 1990s to the beginning of the twentyfirst century. ${ }^{3}$ Nonetheless, Okin's challenge to the debate was to criticize cultural

\footnotetext{
${ }^{2}$ During the 1980s and the 1990s, I lectured at various schools in Norway and Sweden. One example is the often discussed topic of sex education classes. Many Muslim parents wanted to take their children out of these classes, whereas teachers in general held the view that 'as we live in Sweden they have to follow the Swedish system'.

${ }^{3}$ It is important to note that Kymlicka's 1995 books, The Rights of Minority Cultures and Multicultural Citizenship: A Liberal Theory of Minority Rights, deal mainly with ethnic and national minorities, indicating historical established groups. His book from 2007, Multicultural Odysseys. Navigating the New International Politics of Diversity, includes on the other hand discussion of the 'new' immigrant communities in Western countries. Okin's criticism of Kymlicka is however built on his writings from the mid-1990s. The development particularly in the European discourse of multiculturalism in the beginning of the twenty-first century has mainly been on the 'new' immigrant communities indicating the rapid shift of emphasis in only a decade.

It is however important to draw attention to the fact that, for instance, the Swedish debate has been different, probably partly due to the lack of an extensive public debate on the Sami question, and partly
} 
practices, claiming individual rights for women (and children) in minority communities on an equal footing with women belonging to majority populations in Western countries. $^{4}$

\section{'Multiculturalism' versus 'Diversity'}

There is often a confusion of conceptual understanding in discourses on 'multiculturalism'. Tariq Modood's observation in 1997 that the term 'multiculturalism' as well as multicultural policy in general is understood differently by different states according to their particular socio-political and cultural background is still valid (Modood 1997). Whereas most nation-states today consist of more than one cultural community and can thus be said to be 'multicultural societies', very few societies are 'multiculturalist societies', in the sense of cherishing and encouraging more than one cultural approach, incorporating more than one cultural approach into the majority system of belief and practice, and respecting the cultural demands of all or more than one of the nation-state's communities. ${ }^{5}$ This is also true for the Scandinavian countries as the above mentioned Swedish example of change in concept from 'multiculturalism' and 'multicultural society' to 'diversity' (mångfald) indicates. 'Diversity' in the context of the US implies positive experiences from working places with a physically and culturally diverse workforce (see for instance Wood 2004). 'Diversity' particularly in

due to the effort made by David Schwartz who as early as the 1960 s wrote about Sweden as a multicultural society (Schwarz 1965).

${ }^{4}$ It is important to draw attention to the fact that some of the criticism Okin met was built on the concept of minorities as deprived of rights in majority society. For instance, Homi K. Bhabha and Bhikhu Parekh's critical notes to Okin's article tend to have little validity in the context of Sweden and Norway. Bhabha writes, for instance, of: 'The deprivation and discrimination that shape their [minorities'] affective lives, often alienated from the comfort of citizenship [in the metropolitan cultures of the West]' (Bhabha 1999; see also Parekh 1999). In Sweden and Norway immigrants who are granted stay permits would have nearly similar rights as citizens. It is mainly in the right to vote in local and national elections where non-citizens would have 'less rights' than citizens. Moreover, most non-citizens after a certain amount of years of residence have the possibility to obtain citizenship.

${ }^{5}$ See Parekh (2000:4-5) for a discussion of the terms 'multicultural' and 'multiculturalism'. 
the Swedish context, but even in Norway, indicates labour integration of immigrants. It is also worth noticing that in both Sweden and Norway the legal system is to a great extent based on individual rights, and the issue of introducing religious laws or collective rights to the new immigrant communities has not been on the agenda in a similar fashion to that in Canada, for instance. One exception in Norway is the right for religious associations (trossamfunn) to organize their own activities freely with little involvement from the state. ${ }^{6}$ This means that the associations might get state funding although they do not have to follow the law of equal gender opportunities or nondiscrimination when it comes to homosexuality etc. Another issue which at first sight might seem to be an exception to the individual rights pattern in Sweden and Norway, namely religious associations' legal right to marry couples (vigselrett/vigselrätt), might not definitively be regarded as a collective right, as it is the Swedish and the Norwegian states that appoint the particular persons who can perform the marriage ceremony, e.g. the matter is not handled from within the community. Nevertheless the notion that religious associations can obtain the legal right to perform marriage ceremonies might send signals to religious minorities that there might be options for further rights or plural legislation within family law.

Despite the clear lack of the Scandinavian states' commitment to multiculturalist policies, the discourse of multiculturalism or pluralism seems to linger on in both countries, maybe as a result of the international debate on multiculturalism. It is also, as will be shown below, a tendency that some religious leaders consider the state as a multiculturalist state due to this discourse, thus regarding the possibility to follow group norms and laws as an option in a modern Scandinavian society. This happens despite the many indications that the two states mainly deal with their citizens on an individual level when it comes to laws and regulations in society.

It is possible to regard the discourse of multiculturalism as a reason why some minority leaders experience an opening towards legal pluralism. Moreover, there is a certain

\footnotetext{
${ }^{6} \mathrm{http} / /$ www.regjeringen.no/nb/dep/bld/dok/nouer/2008/nou-2008-1/8.html?id=496398
} 
tension between collective and individual rights within the political systems in both Norway and Sweden. As for the Swedish state, for example, the authorities tend to deal with groups and particularly with religious associations in a different manner than with individuals. Yasemin Soysal discusses the Swedish society in terms of "corporatist society' (Soysal 1994). She claims that in Sweden, as in Holland, social organizations consisting of among others immigrants, women, professionals, etc., are controlled by the state and social participation is to a great extent organized around corporatist organizations and their functions (Soysal 1994: 37-8). In this type of corporatist society the state is responsible for incorporating immigrants in a standardized protection and service perspective. Soysal sees this pattern as an official incorporation of new citizens with stress on welfare rights. It might appear that the Swedish state has two approaches to its citizens, an individual and a collective. On the one hand is the corporatist system, where citizens through membership in groups might demand group rights, such as economic support for religious and cultural activities, or rights such as time off on religious festivals or at prayer time. On the other hand there is the individual-oriented approach, which Berggren and Trägårdh name 'state individualism' (statsindividualismen), in which the state relates directly to the individual (Berggren and Trädgårdh 2006). This tension between the individual and the collective approach might be understood differently by the authorities and the minority leaders and members. These two approaches might be regarded by the authorities as two sides of the same coin; independent individuals have their freedom to organize themselves in order to obtain a certain degree of influence in public life. The minorities, on the other hand, might understand the tension between collective and individual rights as an opening up for collective rights.

Moreover, on an international level, the International Convention for Civil and Political Rights (ICCPR) of 1966, ratified both by Sweden and Norway, indicates collective rights as part of the human rights paradigm. The notion of multiculturalism is probably an implicit outcome of Article 27 of the ICCPR with its stress on community and right to 'culture' (Roald 2009, a notion which since the 1970s has been a strong underlying 
force particularly in Sweden. Similarly to the Declaration of Human Rights, the ICCPR also speaks in terms of the rights of individuals. It is, however, the reference to culture and religion that might have been the incentive for the emphasis on cultural rights apparent in new legislation on cultural pluralism in many countries from the 1970s onwards. In Sweden for instance, the multicultural policy of 'equality between Swedes and immigrants' and the possibility for immigrants and minorities to choose 'Swedish culture' or 'to maintain and develop their original culture' was accepted by Parliament in 1975 (Ring 1995: 159, see also Prop 1975: 26). This trend towards cultural pluralism was, however, not labelled as 'multiculturalism', but as a policy of freedom of choice for 'members of linguistic minorities domiciled in Sweden' between 'retaining and developing their original cultural identity and assuming a Swedish cultural identity' (SOU 1974, see also Sander 288). The tension between individual and collective rights becomes apparent by looking at how the understanding of this Swedish on-the-surface policy of 'multiculturalism' was understood differently by official representatives and members of minority communities. The Swedish authorities understood their multicultural declaration of equality (jämlikhet), freedom of choice (valfrihet) and partnership (samverkan) (SOU 1974: 69:93-6, see also Borevi and Strömblad 2004:153) mainly in terms of equality, meaning 'equality between universal individuals regardless of culture, ethnicity, race, religion and gender' (Sander 1996:274). Immigrants, on the other hand, tended to regard multiculturalism in terms of equal right to freedom of choice in religion, ethnicity, and cultural expressions. ${ }^{7}$

It is also interesting to note that about the same time that the governmental bill about immigrant issues was launched, the Swedish authorities legislated on gender-equal opportunities as well as immigration restrictions. This legislation has partly to be regarded as a result of the authorities' understanding that labour immigration was more

\footnotetext{
${ }^{7}$ See even Anwar (1987), for a discussion on how immigrants understand 'integration' as 'acceptance by the majority of their separate ethnic and cultural identity' (1987: 110), whereas the majority sees 'integration' in terms of 'any group unabsorbed, or not assimilated, is considered to upset the equalization of social relations in the society' (1987: 9).
} 
complicated than had been estimated in the 1960s with the economic boom (see for instance Schwarz 1965; 1971; 1973), although social reform was also a driving force in the Social democratic gender equality policy (Florin and Nilsson 1999). Whatever the case, equal opportunity legislation has become one of the most important political hallmarks both in Norway and Sweden from the mid-1970s.

To illustrate the discrepancy between the authorities and the immigrant leaders in understanding state policy, I will draw attention to an incident in Sweden in the run up to the parliamentary election in the autumn of 2006. The Swedish authorities have, as stated above, never voiced the intention of accepting legal pluralism. ${ }^{8}$ An Islamist belonging to the ikhwan trend, ${ }^{9}$ Mahmoud Aldebe, former head of one of the Muslim organizations and a frequent participant in the public debate, had a different opinion, however. In April 2006 he distributed a letter to all the political parties (Aldebe 2006). He referred to various issues which he regarded as important for the Muslim community in Sweden, such as the right to leave from work to attend religious festivals, to have a mosque in every city, to have gender-specific sessions in public indoor swimming pools, and to introduce sharia law in family matters for Muslims in Sweden. The important point in this case is that Aldebe particularly referred to the principle of freedom of religion and to the UN conventions 'which Sweden has ratified'. In his view this 'implies the right to a distinctive legislation (särlagstiftning)', particularly in family issues. It is clear that Aldebe understands Swedish multiculturalism as a system open to legal pluralism. Furthermore, Aldebe's understanding of UN conventions in collective terms became obvious in his claim that the Swedish law of freedom of religion in contrast to the recommendations of the UN conventions (probably the ICCPR) is built

\footnotetext{
${ }^{8}$ I have discussed 'the right to marry couples' (vigselrätten), a right for religious communities, elsewhere (Roald 2010). In a sense this right can be regarded in terms of legal pluralism, although most probably legal pluralism not been the intention of giving this (collective) right to different religious organisations.

${ }^{9}$ It is difficult to state a particular belonging for Islamists in Europe as most Islamist movements have secret membership. Islamists within the ikhwan trend are thus those persons who are either members of the Muslim Brotherhood or sympathize with this movement's ideology.
} 
on 'an individualised concept of religion'. In Aldebe's Islamistic view 'Islam' is a system where all rules, values, rituals, and even the Arabic language belong to religious expression, and the concept of religion must therefore, in his view, be broadened in the Swedish context in order to include such expressions. Aldebe's argumentation points at the tension between individual and collective rights in the UN conventions as well as in the Swedish official policy.

Some activists, particularly from minority communities, as the example of Aldebe indicates, tend to claim legal pluralism, where minority communities have equal formal, legal, and constitutional executive positions with the majority, i.e., the minorities should be entitled to live according to their nomos (the community's normative universe where legislation and cultural structures are intertwined) (Shachar 2001:2). However, Aldebe's stress on the private sphere of family matters, such as marriage, divorce, custody and heritage, reflects Okin's claim of women being oppressed in the name of multiculturalism, as family legislation in Islam is built on a gender hierarchy with male supremacy. In contrast, the authorities promote rights for minorities to practise religion in terms of prayer, festivals, and to a certain extent dress, ${ }^{10}$ but at the same time they tend to stress the protection of every human being's right to obtain his or her individual rights in society. ${ }^{11}$ As some representatives from the religious minorities stress the concept of equality on a group level, i.e. each groups' right to profess their culture, they tend to overlook or disregard how the concept of gender equality has become one of the most important aspects within this general social equality. Thus, the tension between the collective claim of group equality and the individual claim of every human being's equal rights, particularly women's equal opportunities with men, seems to be the main focus in the debate on multiculturalism in Sweden and Norway.

\footnotetext{
${ }^{10}$ In Norway and Sweden women wearing the hijab are protected against explicit discrimination, and the face-veil is not forbidden, as it is in France, for instance.

${ }^{11}$ See the discussion above about exceptions for religious associations in Norway.
} 
In this context it is important to draw attention to the multicultural claim of the individual's right to leave his or her community; the right to live according to the community's nomos presupposes the right to leave the community (Kukatha 1992:116). This freedom of choice to remain or to leave the community reflects the Swedish liberal model where immigrants and minorities can either choose 'Swedish culture' or maintain and develop their original 'culture'. The aspect of choice was also one of Roth's concerns in his 1996 work on borders for multicultural practice. His claim is that children's rights should not be restricted by their parents' culture. 'If children are not allowed to take part in other cultures', he says, 'then their acceptance of the 'traditional' culture would not be an expression of an independent choice.' (Roth 1996:92). His solution is 'dialogues without prestige', but it is interesting that in his discussion he seems to favour a cultural change among immigrants towards a Swedish position (Roth 1996:94). Thus it seems that Roth is aware of the tension between freedom of choice and cultural claims within minority groups. The Swedish model might seem 'liberal', in the sense that every individual has the freedom of choice to associate or to dissociate with a cultural/religious community. However in practice it might not be as simple. By looking at Muslim communities, women, young girls and sometimes even boys who want to leave their community might be stopped, sometimes violently as was the case with for instance a Kurdish woman, Fadime (see for instance Wikan 2008). Sweden has had a relatively high number of honour-related killings in recent decades, the latest, a young woman from the Yazidi community who was killed in April 2012. Her brother is suspected of having murdered her two-year-older sister and is now in custody. ${ }^{12}$

Moreover, socialization within collectivistic communities tends to create a symbiotic relationship between members of the group making it difficult for some to dissociate from the community. Those who would prefer both to live according to the majority society's value system and be part of the social setting of their cultural community might lose an important part of their social network. This, due to the minority's understanding of the majority's acceptance of minority groups living according to their

\footnotetext{
${ }^{12}$ http://www.aftonbladet.se/nyheter/article14767793.ab
} 
nomos, might strengthen the notion of group solidarity at the price of loyalty and solidarity with the majority. Moreover, as minorities perceive that it is acceptable to live according to minority values and morals, a minority thinking imposing identity policy in various forms on members of the community might be created. Muslim women marrying non-Muslim men, a forbidden act according to the traditional collectivistic Islamic law schools, would for instance put them at risk of suffering violence in the name of 'honour' or being regarded as social outcasts (Roald 2009).

The issue at stake in the discourse of multiculturalism is whether 'multiculturalism' is actually about fixed and unalterable cultures on the one hand, and elitistic understandings of which elements minority 'cultures' consist of, on the other. A consequence of this notion is that, as 'culture' is commonly regarded in processual terms as well as every 'culture' consisting of various forms and shapes, is the discourse of multiculturalism necessary? This particularly as the multiculturalist discourse only to a certain extent reflects the social reality in Sweden and Norway. Would not cultures eventually amalgamate and would not a new 'culture' surface in every immigrant country? And the most important consequence of this processual concept of culture is: Would not multicultural policy solidify traditional cultural structures instead of letting immigrants adjust to a slow social change inherent in cultural encounters in general? And to draw the question into the religious sphere: Are the existing religions homogenous as well as fixed and static systems not prone to change? In contrast to this consequence analysis of processual concepts, such as identity and culture etc., the philosopher Charles Taylor's discussion of the link between identity and recognition indicates how this issue has been treated in the multicultural debate. Implicitly he portrays a group's identity as unalterable and static, even though he explicitly states that a person's or a group's identity is always defined in dynamic interactions. ${ }^{13}$ Similarly, the Archbishop of Canterbury, Rowan Williams, in his controversial lecture in February 2008, discussed the aspects of flexibility and change within Islamic jurisprudence, and yet at the same time opened the way for a possible plural jurisdiction, where some

\footnotetext{
${ }^{13}$ See Baumann (1999) for a critique of Taylor's concept of identity.
} 
aspects, especially religious marital legislation, might co-exist with British legislation (Williams 2008). In view of the archbishop's, as well as many Islamic scholars', claim of Islamic legislation as flexible, is it thus not possible that Islamic expressions might eventually turn in the direction of a human rights perspective with emphasis on individual rights?

In order to see if the discourse of multiculturalism has hindered developments among Muslims in Sweden and Norway I will turn to Seyla Benhabib's idea that '[i]dentity/difference politics is afflicted by the paradox of wanting to preserve the 'purity of the impure' and the 'immutability of the historical' (Benhabib 2002:11). Multiculturalism promotes identity policies, and as indicated by the above example of Aldebe, the Muslim leader in Sweden, the immigrants' notion of Sweden as a multiculturalist state has led some Muslims to accentuate identity policies despite the state approach of individual rights in both Norway and Sweden. The following discussion will deal with Benhabib's two concepts of 'purity of the impure' and the 'immutability of the historical' in order to investigate Islamic expressions among Swedish and Norwegian Muslims.

\section{Purification of the Impure}

The pervasive notion in Muslim communities of Islam as 'one Islam' is an illustration of Benhabib's concept of 'purification of the impure'. In contrast to this ideal of a homogenous Islam, there are a multitude of understandings and practices of Islam in Muslim communities. This is also noted by Nielsen as it comes to Islamic views of sharia (Nielsen and Christoffersen 2010:5ff). Most Muslim minority communities in Western countries today tend to be dominated by leaders with collectivistic theological approaches to the religious texts, particularly in gender issues (Roald, 2001; 2005). This theology was mainly created by male scholars in particular historical periods and in particular social settings quite different from modern society. Muslim leaders in Sweden and Norway tend to have either a traditional collectivistic law-school understanding of Islam (mainly in Pakistani and Turkish communities), or an Islamist understanding (mainly in Arabic-speaking communities but also to a certain extent in Pakistani and 
Turkish communities). The Islamist ideology has to a great extent been manifested in the public discourse as Islam per se, due mainly to the $d a$ 'wa (call to Islam) activities in the Western world from the 1970s onwards. The extensive dissemination of Islamist literature in the form of the Muslim Brotherhood's ideology over the last forty years together with Islamist activities and Islamist leadership in Muslim communities have created an image of Islamism, i.e. 'Islam as a comprehensive system; a way of life' as 'the Islam'. Although Islamists tend to have a 'modern' approach to politics, many of them have a collectivistic law-school approach to gender issues and family law matters. As will be discussed below, however, some Islamists, particularly the post-ikhwan, i.e. sympathizers and previous members of the Muslim Brotherhood who adhere to the movement's ideology but are not organized in the movement (see Roald 2001:54-7), have joined the trend of reinterpreting the Islamic sources in which gender issues have been highlighted.

In contrast to the Muslim leadership, Muslims in general have different ways of relating to Islam and practising their religion. Whereas some follow most religious precepts strictly, others are more relaxed. The difference in ways of practising might have to do with zeal or laziness, but it also has to do with understanding and interpretation of the religious texts. The issue is whether the Islamic texts are regarded as to be understood literally or whether Muslims see it as possible to deduce Islamic principles from the texts. For instance, whereas some Muslims believe that the wearing of the Islamic headscarf/faceveil is an obligatory Islamic precept regardless of geographical locations, others believe that indeed there are some references to women's covering in the Koran, but do these texts talk about the covering of the head and/or the face or do they refer to a general principle of 'decent' dressing? Moreover, an issue which has been raised lately is: should the Koranic verse 33:59 saying that Muslim women should 'draw their cloaks (jilbab) close round them', as 'this will be better, so that they may be recognized and not annoyed', be understood as not wearing the headscarf/faceveil in Western countries where women actually might be 'annoyed' when wearing the Islamic dress, 
whether headscarf or faceveil? The issue of 'veiling' is thus an illustration of variations; i.e. impurity, in an illusion of a 'pure' and homogeneous Islamic tradition.

Difference in educational backgrounds is also an issue of importance. Many firstgeneration Muslim immigrants have little formal education and this influences their understanding and approach to Islam. Many of their descendants, the second-generation Muslims, however, tend to approach Islam according to the majority society's values of individual rights (human rights), gender equality, and private religiosity in terms of religion being separated from politics and individualized (for instance fatwa-shopping on the web and picking and choosing the religious content). The example of Bushra Ishaq, a Norwegian Muslim woman with parents from Pakistan, illustrates the individualization process among second-generation Muslims. Ishaq was a medical student and the leader of the Muslim Student Association (Muslims Studentsamfunn, MSS) in 2009 when she wrote an editorial in the biggest Norwegian newspaper Aftenposten under the title 'Muslims in change'. She argues that due to their high educational standards, young Muslim women in Norway tend to interpret and understand the Islamic sources in a different way than their parents. She wrote:

We struggle for the realization of ourselves as independent individuals as we as Norwegian girls have been socialized into the fight for [gender] equality. Without the Norwegian culture's fundamental influence and the values of the welfare state, which gives equal right to every citizen, the growing Muslim feminism would not be a reality. (Ishaq 2009)

It is interesting how Ishaq explicitly links Islamic development to Norwegian influence and particularly the welfare state. Her stress on the 'independent individual' further reflects how the individual-oriented perspective influences members of minority groups. In Nielsen's terminology it is possible to name her attitude as a 'high-profile integration approach', in the sense that she attends to Norwegian societal ideals and at the same time is 'critically reviewing the Muslim tradition as it effects religion and cultural tradition' (Nielsen 2010:12). It is important to note, though, that in the case of new 
interpretations and particularly as it comes to gender issues, the notion of a 'pure' or 'one' Islam is also a strategy from the new generations of Muslims in Norway and Sweden, as indicated by Ishaq's text. She writes, for instance, that 'young Muslims look upon the religion in a different way than our parent's generation' and she continues, 'Even though it is hard for many in the West to differentiate between culture and religion, there are many things in the Pakistani culture which opposes Islamic theology' (Ishaq 2009). The 'one' Islam for many of these is an understanding of Islam as compatible with individual rights, democracy, and tolerance-watchwords in contemporary Scandinavia. As these new generations of Muslims have gone through the Scandinavian educational system where these values are taught from an early age, these values tend to become 'Islamic' in their worldview (see Roald 2005).

A final issue to discuss is the variation of practices and understanding of Islam in the different Muslim ethnic and national communities in Norway and Sweden. Is the Somali understanding of female circumcision as 'Islamic' the 'true Islam'? Is 'honour' violence when it comes to 'illegitimate' sexual relations or suspicion of such relations an Islamic phenomenon, as some Muslims from, for instance, Afghanistan and the Middle East tend to believe? Does 'Islam' promote gender equality or endorse peace as many second-generation Muslims consider true? What then is 'Islam' and what is Muslim 'culture'? As shown above, the discrepancy between Aldebe's and Ishaq's view of what Islam is indicate a flux of thoughts and notions, e.g., a process of ideas rather than a purification and a homogenization of a religious tradition.

As Benhabib has pointed at, multiculturalism tends to be about purification of the 'impure', and homogenizing of the heterogeneous. Culture and religion are not homogeneous entities as shown by Ishaq's approach to gender issues in Islam, and Muslim leaders' efforts to try to identify specific cultural or religious expressions which are supposedly 'genuine' in each cultural and religious community might be virtually impossible. However, as also noted above, the purification of the impure is also used by new generation Muslims in order to reject cultural traits which are not seen as compatible with 'modern' human rights values. Thus the purification of the 'impure' at 
least on a micro level might be an agent of change within the Muslim communities, despite the attempt from the first-generation Muslim leaders to reinforce collectivistic cultural and legal (Islamic law-school) perspectives in the process of 'purifying' the 'impure'.

\section{'Immutability of the Historical'}

The vital question is whether a religion, and in the present context, 'Islam' really is a fixed and static system as commonly believed, or whether the Islamic tradition, as other religious systems have proved to be, is in a flux of change, as also shown above. The common notion of Islam as static and unchangeable reflects Benhabib's idea of how identity politics is about the attempt to preserve the 'immutability of the historical'. The point at stake is whether Islam is understood in the same way today as in the past in its formative period? Islamic legal rules were consolidated in a time when social developments, political systems, and social relations were based on collective rights and family adherence. This socio-political structure is in contrast to contemporary Norwegian and Swedish society. Whereas some Muslims tend to live in segregation from the majority society with social networks mostly in their own communities, in Nielsen's terminology the 'high-profile segregation' approach, many Muslims participate in majority society in schools, at work, and in socio-political and economic activities and-like Ishaq - their approach is one of 'high-profile integration' (Nielsen 2010:11-12). Although the latter goes for some from the first-generation Muslim immigrant communities, it is particularly the new generations of Muslims, who to a great extent are socialized into majority society through schools, friends and the public discourse, who tend to be influenced by majority cultural ideas and thought. One example is the view of gender equality. As most first-generation Muslim immigrants believe that women and men have equal worth but different social roles in Islam, their children tend to see Islam in terms of gender equality. In a study on gender equality in 2005, I discovered how the first-generation practising Muslims in Norway claimed that there is no gender equality in Islam, whereas their children, particularly those with higher education and with an Islamic orientation, claimed that Islam is gender equality. 
This example indicates the strong stand of gender equality in Norwegian society. As children attend Norwegian schools, they are culturally socialized into the pattern of equal gender opportunity and link this 'positive' value to their faith. ${ }^{14}$

Even the notion of female leadership has come under scrutiny lately, on a global level, due to influences from Islamists living in Western countries and pressure from the UN Convention on the Elimination of All Forms of Discrimination Against Women (CEDAW). It is worth noting that Norway and Sweden are among the few countries where Islamic communities have elected women in positions as top leaders of Muslim organizations. Even Muslim organizations on a lower level have elected women as leaders. Bushra Ishaq was for instance the elected leader of the Norwegian organization Muslim Students Association (Muslimsk Studentsamfunn) in 2009 and one of the local mosques in the north of Norway also has a female convert its top leader. ${ }^{15}$ In view of the general prohibition against female leadership in the traditional law-school understanding of Islam it is obvious that there is an ongoing change in the Islamic communities in Scandinavia. The consequence of an idea of society's multicultural policy might be the impediment of such changes as the notion of multiculturalism, as shown by the example of Aldebe, creates a tendency to encourage cultural differences instead of the synthesis of different cultural expressions in the cultural encounters in a plural society. However, as indicated above, in Sweden and in Norway changes towards more individual-oriented and human-rights perspectives have started to gain ground in Muslim communities, particularly as the new generations of Norwegian and Swedish Muslims grow up and attain important public positions. It remains to see how influential this trend will be in the future.

\footnotetext{
${ }^{14}$ See for instance Sayyid (1997) for a discussion of how the 'good' values become 'Islamic' in new cultural settings.

15 ‘126 moskéer- én kvinnelig leder', Vårt Land, 20 January 2010. Accessed 27 May 2013, at http://www.vl.no/samfunn/article8675.zrm
} 
Traditional legislation, most often promoted by men and religious leaders, indicates that the cultural content of minority communities in the secular state will often consist of the hegemonic ideology instead of alternative interpretations of the holy texts. This is particularly apparent in family legislation. Traditionally speaking, both in Judaic and in Islamic legislation, women have difficulties, for instance, obtaining a divorce against the will of their husbands. This pertains to religious minorities in Western countries, but even to countries with Muslim majority populations, as well as to Israel where the family law is based on traditional collectivistic interpretations of the Jewish scriptures. It is thus more common for Muslim and Jewish women in minority communities to be victims of 'limping' marriages, i.e. being divorced in one legal system (the secular state) and married in another legal system (the religious), than men. In a study on divorce instigated by wives in Sweden from 2007 onwards, I discovered how some women who were divorced according to the Swedish legal system could not get their Islamic divorce if their husbands had refused to sign the divorce document in the Swedish court. In Sweden the divorce is effective after six months, even if one of the parties repudiates it. The result is that these women have difficulties in remarrying due to psychological factors such as being excluded by the group if they remarry without obtaining the Islamic divorce, or, if they were married in a Muslim country, they would be regarded as committing bigamy and thus punished if they remarry without having an accepted Islamic divorce certificate (see Roald 2010).

Lately, discussions within Muslim communities in Norway and Sweden indicate a change in the field of family legislation. The new generation of Muslims, men and women, are influenced by the human rights discourse of gender equality (Nielsen and Christoffersen 20010; Roald 2005). Even on a global level, the increase in women with higher education in Islamic studies as well as in other academic fields has had an impact on the Muslim leadership. It is interesting to note that the European Council of Fatwa and Research, based in Ireland and headed by the notable Islamist, Yusuf al-Qaradawi, for instance has discussed whether a divorce in the secular Western societies should count as an Islamic divorce. There is a disagreement within the Council, but the Sunni 
decentralized and thus individualistic approach (that every Muslim is in principle free to follow the scholar of his or her own choice) has made it possible for some women to adhere to those scholars who promote the idea of a secular divorce equalling an Islamic divorce. However, many women are still rejected by their communities and by legal systems in Muslim countries as bigamists if they remarry without an Islamic divorce document (Roald 2009).

It is also worth looking into the difference in understanding of sharia and family issues in Sweden between the first-generation Arabic-speaking Islamist Aldebe, mentioned above, and the Muslim political activist with a pronounced Islamic orientation, Mehmet Kaplan, of Turkish origin. They both belong to the Muslim leadership but Aldebe, who came to Sweden as an adult, is a proponent for introducing Islamic family legislation in Sweden, as 'it is family legislation which is important for Muslims in Sweden; marriage, divorce, custody of children, etc.' (Dagens Nyheter 27 April 2006). Aldebe's concept of sharia reflects the practice of ancient rulers in the Muslim empire of distinguishing between family legislation, dealing with the private sphere and subordinated to the Islamic scholars, and the rest of sharia legislation, dealing with the public sphere and subordinated to the political leadership. Kaplan, on the other hand, who came to Sweden as a young child, decisively rejects Aldebe's claim, saying that it is completely 'taken out of the air' (Dagens Nyheter 28 April 2006). Kaplan's attitude reflects the secular society's norm of legal gender equality. This example illustrates both the heterogeneity of ideas in the Muslim community, as well as the development of Islamic ideas, in both a historical and national context. As the example of Aldebe and Kaplan indicates, the first-generation Muslim immigrants are more prone to adhere to a traditional and collectivistic theology, whereas second-generation Swedish and Norwegian Muslims are more tuned into a human rights perspective of secular society. ${ }^{16}$

\footnotetext{
16 There are also examples of first-generation European Muslims who tend to end up in rigid belief systems such as salafism and some might even develop a radical, violent approach to the Islamic sources, such as those involved in the events of 7/7 2005 in Great Britain. However in my research I have discovered a stronger general tendency towards a human rights perspective among the new generation Muslims than a trend towards extremist understandings of 'Islam', without denying its existence.
} 
Traditional sharia legislation is a product of a society different from that of contemporary Europe. Moreover, Muslims on a global level differ concerning the content of sharia, i.e., which sharia legislation should be applied in countries with Muslim majority populations and in Muslim communities in the West; the traditional law-school rules or rules more in line with the human rights perspective? In addition is the wide spectrum of views among Muslims of whether sharia legislation indeed is desirable or not in the European context. It is interesting to note that many Muslim women's organizations in Canada protested against a proposal at the beginning of the last decade, to introduce sharia in Canada (Hogben 2005). ${ }^{17}$ Thus, the suggestion of opening up for religious legislation made by the Archbishop of Canterbury would probably create more problems than it would solve. ${ }^{18}$

Benhabib's idea of multiculturalism as a preserver of the 'immutability of history' is important to consider in view of the examples above. It is obvious that Muslims in minority communities go through profound changes of belief and practice, due on the one hand to the constant cultural encounters as well as discussions in the public space, where the majority society contests Muslim belief and practice, and on the other due to the fact that new generations of Norwegian and Swedish Muslims go through the communal school system and are thus socialized into values of human rights and gender equality and private religiosity. $^{19}$

\section{Reflections}

In the context of Norwegian and Swedish Muslim communities, the impossibility to 'purify the impure' in cultural expressions as well as the rapid theological changes going on in contemporary Islam, it is pertinent to ask whether the notion that

\footnotetext{
${ }^{17}$ During a Metropolis conference, 17-21 October 2005 in Toronto, Canada, I attended Alia Hogben's contribution: 'Balancing Gender Equality and Religious Diversity: Muslim Women in Western Societies, Islamic Law \& the Justice System'.

${ }^{18}$ See Shah (2010: $120 \mathrm{ff}$.) for a discussion on the Archbishop of Canterbury's suggestion.

${ }^{19}$ With private religiosity I mean both the tendency to differentiate between secular and religious spheres, as well as the tendency to individualize religious expressions by 'fatwa shopping' on the intErnet or by individual interpretations through personal studies of the Islamic sources.
} 
multiculturalism with acceptance of Muslim cultural and religious practices would lead to a situation where traditional Islamic interpretations will be congealed/frozen in time and space? As shown, Norwegian and Swedish societies are not committed to multiculturalist policies, but the authorities' liberal policies with funding for religious activities, anti-discrimination laws, and a corporatist policy towards minorities have created an image among community leaders of acceptance for multiculturalist ideas. The idea of opening the way for Islamic legislation as it applies to family law would possibly reinforce the collectivistic perspective in Islamic legislation as 'the correct' Islamic understanding. It is even pertinent to ask whether the Norwegian authorities' acceptance of internal dealings by religious associations in matters of leadership and marriage ceremonies for homosexuals would also be an obstacle for a rapprochement of Islamic interpretations with liberal individualistic human right ideas, a development many Christian and Jewish groups have gone through. Particularly for minorities living in Western countries with the possibility of a dynamic interaction with other minorities and majority society it is important to see culture and religion in terms of processual changes which can make it possible to empower weak and vulnerable sectors within the community such as women, children and homosexuals. As indicated above there are changes towards a more 'Norwegian' and 'Swedish' understanding of Islam. Whether this is a result of the 'liberal' Swedish and Norwegian policy model of freedom of choice is difficult to evaluate; the right to remain or to leave the community is a matter of hardship particularly in Muslim communities, as the collectivistic socialization into the family and community tend to be a severe obstacle for the individual choice to adhere to Swedish/Norwegian 'culture'. Despite this, however, there are changes towards a more individual-orientated understanding of Islam, but the issue at stake is whether these changes would have more fertile ground in a society where individuals rather than communities are favoured. This approach reflects Tariq Ramadan's idea of a 'sense of belonging' 20 where Muslim immigrants and their descendants attach

${ }^{20}$ Tariq Ramadan talked about 'sense of belonging' in a lecture on religion given at the Norwegian Academy of Science, 1-2 November 2007. 
themselves to the Norwegian and Swedish social system, particularly the family law system, rather than searching for legal plurality. Islamic family legislation is already a plural system with various countries with Muslim majority populations having different laws.

An obvious trend in the Muslim communities in Norway and Sweden is the discrepancy between some of the Muslim leaders belonging to the first-generation immigrant communities and the second-generation Norwegian and Swedish Muslims. Whereas the ideal of multiculturalist policies with the emphasis on traditional Islamic law-schools in family matters seems to be an ideal for leaders such as Aldebe, the Norwegian Muslim Ishaq tends to conflate Islamic expressions on gender relation with the Norwegian ideal of equal gender opportunities. The conflict between Aldebe and Kaplan further reinforces this generational shift of Islamic understanding.

The discourse of multiculturalism might have had a hindering effect for developments in religious and cultural changes among the first-generation Muslim immigrants. However as it comes to the next generation, the first generation Swedish and Norwegian-born Muslims, the Norwegian and Swedish societies seem to have affected their understanding of Islam towards a human rights and a gender equality paradigmessential values in these two societies.

\section{References}

Aldebe, Mahmoud, 2006: Letter: 'Ett öppet brev till alla svenska politiska partier som deltar I årets val' ('An open letter to all Swedish political parties participating in the annual election').

http://sverigesradio.se/diverse/appdata/isidor/files/83/2113.pdf. Accessed 4 January 2014. 
Andersen, Torben M. and Molander, Per, 2003: "Introduction", in Andersen and Molander (eds.): Alternatives for Welfare Policy: Coping with Internationalisation and Demographic Change, Cambridge University Press, Cambridge, pp. 1-22.

Anwar, Muhammad, 1987: "Religious Identity in Plural Societies: The Case of Britain", in Journal of the Institute of Muslim Minority Affairs 2, 2/3.1.

Baumann, Gerd, 1999: The Multicultural Riddle. Rethinking National, Ethnic, and Religious Identities, Routledge, London.

Benhabib, Seyla. 2002: The Claims of Culture. Equality and Diversity in the Global Era, Princeton University Press, Princeton and Oxford.

Berggren, Henrik och Trägårdh, Lars, 2006: Är svensken människa? Gemenskap och beroende i det moderna Sverige, Nordstedts, Stockholm.

Bhabha, Homi K., 1999 (1997): "Liberalism's Sacred Cow", in J. Cohen and M. Howard (eds): Is Multiculturalism Bad for Women? Princeton University Press, Princeton NJ.

Borevi, Karin and Strömblad, Per, 2004: Engagemang, Mångfald, Integration, Stockholm: SOU (Swedish Governments Official Reports) 2004: number 49.

Brochman, Grete, 2003: "Welfare State, Integration and Legitimacy of the Majority. The Case of Norway", in Jeroen Doomernik and H. Knippenberg (eds): Migration and Immigrants. Between Policy and Reality. A Volume in Honor of Hans van Amersfoort, Aksant Academic, Amsterdam, pp. 42-67.

Eriksen, Thomas Hylland, 1997: "Multiculturalism, Individualism, and Human Rights" in Rickard A. Wilson (ed.): Human Rights, Culture and Context, Pluto, London, pp. 49-69.

Eriksen, Thomas Hylland, 2001: "Between Universalism and Relativism: A Critique of the UNESCO Concept of Culture", in J. Cowan, M-B. Dembour, and R. Wilson, (eds.), Culture and Rights. Anthropological Perspectives, Cambridge University Press, Cambridge, pp. 127-48.

Florin, Christina and Nilsson, Bengt, 1999: "Something in the Nature of a Bloodless Revolution: Gender Equality Policy in Sweden in the 1960s and 70s", in Rolf 
Torstendahl (ed.): State Policy and Gender System in the two German States and Sweden. Opuscula Historica Upsaliensia, Uppsala, pp. 11-77.

Ishaq, Bushra, 2009: "Muslimer I endring” I Aftenposten, 15 September 2009. http://www.aftenposten.no/meninger/kronikker/article3252237.ece._Accessed 25 May 2010.

Kukatha, Chandran, 1992: “Are There Any Cultural Rights?” in Political Theory (SAGE), 20, 1: 105-139.

Kymlicka, Will, 1995a: The Rights of Minority Cultures, Oxford University Press, Oxford.

Kymlicka, Will, 1995b: Multicultural Citizenship: A Liberal Theory of Minority Rights, Oxford University Press, Oxford.

Kymlicka, Will. 2007. Multicultural Odysseys. Navigating the New International Politics of Diversity, Oxford University Press, Oxford.

Modood, Tariq, 1997: "Introduction" in T. Modood and P. Werbner The Politics of Multiculturalism in the New Europe: Racism, Identity, and Community, Zed Books, London and New York.

Nielsen, Jörgen S, and Christoffersen, Lisbet, 2010: Shari'a as Discourse: Legal Traditions and the Encounter with Europe, Ashgate, Farnham.

Okin, Susan Moller, 1999 (1997): “Is Multiculturalism Bad for Women?” in J. Cohen and M. Howard (eds.): Is Multiculturalism Bad for Women? Princeton University Press, Princeton NJ. http://www.bostonreview.net/BR22.5/okin.html. Accessed 16 October 2009.

Parekh, Bhikhu, 1999 (1997): “A Varied Moral World” in J. Cohen and M. Howard (eds.): Is Multiculturalism Bad for Women? Princeton University Press, Princeton NJ. http://www.bostonreview.net/BR22.5/parekh.html. Accessed 19 October 2009.

Parekh, Bhikhu, 2000: Rethinking Multiculturalism. Cultural Diversity and Political Theory, Palgrave, New York. 
Ring, Hans, 1995: "Refugees in Sweden. Inclusion and Exclusion in the Welfare State" in R. Miles and D. Tränhardt (eds): Migration and European Integration. The Dynamic of Inclusion and Exclusion, Pinter, London, pp. 159-176.

Roald, Anne Sofie, 2001: Women in Islam. The Western Experience, Routledge, London.

Roald, Anne Sofie, 2005: Er Muslimske Kvinner Undertrykt?, Pax Forlag, Oslo.

Roald, Anne Sofie, 2009: Muslimer i Nya Samhällen. Individuella eller kollektiva rättigheter, Daidalos, Göteborg.

Roald, Anne Sofie, 2010: "Multiculturalism and Religious Legislation in Sweden" in H. Moghissi and H. Ghorashi (eds): Muslim Diaspora in the West. Negotiating Gender, Home, and Belonging, Ashgate, Burlington.

Roth, Hans-Ingvar. 1996. Mångfaldens Gränser, Arena, Stockholm.

Sander, Åke, 1996: "The Status of Muslim Communities in Sweden", in Gerd Nonneman, Tim Niblock, and Bogdan Szajkowski (eds): Muslim Communities in the New Europe. Ithaca, Reading UK.

Sayyid, Bobby, 1997: A Fundamental Fear, Eurocentrism and the Emergence of Islamism, Zed Books, London \& New York.

Schwarz, David, 1965: “Svenskt flerkultursamhälle - en utopi?" in Libertas 6, Stockholm, pp. 14-17.

Schwarz, David, 1971. Svensk Invandrar- och Minoritetspolitik 1945 - 1968, Prisma, Stockholm.

Schwarz, David (ed.) 1971: Identitet och Minoritet.: teori och politik i dagens Sverige, AWE/Gebers, Stockholm.

Schwarz, David, 1973: Kan Invandrarna bli Svenskar? Studentlitteratur, Lund.

Shachar, Ayelet, 2001: Multicultural Jurisdiction. Cultural Difference and Women's Rights, Cambridge University Press, Cambridge.

Shah, Prakash. 2010: "Between God and the Sultana? Legal Pluralism in the British Muslim Diaspora", in J.S. Nielsen and L. Christoffersen (eds):, Shari'a as Discourse: Legal Traditions and the Encounter with Europe, Ashgate, Farnham, pp. 117-139. 
Soysal, Yasmine. 1994. Limits of Citizenship. Migrants and Postnational Membership in Europe. Chicago University Press, Chicago.

SOU (Statens offentliga utredningar: Swedish Government Official Reports), 1974: Investigation of Immigrants 3, Regeringskansliet, Stockholm.

Taylor, Charles, 1994: "The Politics of Recognition", in Amy Gutmann (ed.): Multiculturalism: Examining the Politics of Recognition, Princeton University Press, Princeton NJ.

Wikan, Unni. 2008 [2003]: In Honor of Fadime: Murder \& Shame. University of Chicago Press, Chicago.

Williams, Rowan, 2008: “Archbishop's Lecture - Civil and Religious Law in England: A Religious Perspective", 7 February 2008 http://www.archbishopofcanterbury.org/1575. Accessed 30 November 2009.

Wood, Peter, 2004: Diversity. The Invention of a Concept, Encounter Books, Jackson TN.

\section{Internet}

Barne- Likestillings og Inkluderingsutvalget. NOU 2008: 1. Kvinner og homofile i trossamfunn. http://www.regjeringen.no/nb/dep/bld/dok/nouer/2008/nou-20081/8.html?id=496398. Accessed 12 June 2012.

"Det är en idiotisk sak". Published 2 May 2012 in Aftonbladet.

http://www.aftonbladet.se/nyheter/article14767793.ab. Accessed 12 June 2012.

Government Bill: Prop. 1975: 26. "Proposition 1975:26 Regeringens proposition om riktlinjer för invandrar- och minoritetspolitiken m. m." http://www.riksdagen.se/webbnav/?nid=37\&doktyp=prop\&rm=1975\&bet=26 $\underline{\& d o k \_i d=F Y 0326 . \text { Accessed } 12 \text { June } 2010 .}$

“126 moskéer- én kvinnelig leder” Vårt Land, 20 January 2010. http://www.vl.no/samfunn/article8675.zrm. Accessed 27 May 2013.

\section{Newspapers}

Dagens Nyheter (DN) 27 April 2006. "Muslimskt Förbund kräver egna lagar”. 
Dagens Nyheter (DN) 28 April 2006. "Muslimskt krismöte efter krav på särlagstiftning". 